\title{
Isolation and Culture of Soybean (Glycine max L. Merrill) Microspores and Pollen Grains
}

\author{
Lia Rosane Rodrigues ${ }^{1}$, Bianca de Camargo Forte ${ }^{1}$ and Maria Helena Bodanese-Zanettini ${ }^{1 *}$ \\ ${ }^{1}$ Departamento de Genética; Universidade Federal do Rio Grande do Sul; C. P. 15053; 91501-970; Porto Alegre - \\ RS - Brasil
}

\begin{abstract}
In the last three decades, research on soybean microspore embryogenesis was restricted to anther culture, which presents limitations such as the small number of responsive microspores and the high embryogenic potential of sporophytic tissues. Therefore, a sequence of studies was performed to establish appropriate conditions for the isolation and culture of soybean microspores and pollen grains as an alternative to anther culture. First, a pollen and microspore isolation technique was developed using floral buds from four soybean cultivars (Bragg, IAS 5, MG/BR-46 Conquista and BRSMT Uirapuru). This technique allowed the establishment of cultures with satisfactory density and characteristics. Subsequently, different culture conditions were tested. Although B5 and MS media have been currently recommended for soybean anther culture, the best result was obtained in PTA-15 modified medium, with the formation of enlarged microspores and $0.4 \%$ of multicellular pollen grains in the cultivar BRSMT Uirapuru.
\end{abstract}

Key words: Androgenesis, Glycine max, microspore culture, microspore embryogenesis, microspore isolation, soybean

\section{INTRODUCTION}

Soybean (Glycine $\max$ L. Merrill, 2n=2x=40) microspore embryogenesis has been tried since the early 1970s (Tang et al., 1973; Ivers et al., 1974), mainly through anther culture (Hu et al., 1996). However, a protocol for haploid and doublehaploid plant production is not available so far. Two main factors account for the lack of success in soybean anther culture. First, the small proportion of gametophytic pathway deviation recorded in microspores and pollen grains (Yin et al., 1982; Kaltchuk-Santos et al., 1997). Second, using SSR marker (Rodrigues et al., 2004b) and histological analysis (Rodrigues et al., 2005b), it was proved that culture conditions currently known to trigger microspore embryogenesis favored the occurrence of embryogenesis from sporophytic tissues (Rodrigues et al., 2004a). Isolated microspore culture could provide better conditions for androgenic plant production in soybean. However, to the best of our knowledge, no consistent information is available concerning soybean microspore isolation. In an extensive review, Hu et al., (1996) referred a single report, in which D.P. Liu and G.L. Zhao claimed to have obtained macroscopic calluses from isolated soybean microspores in 1986.

In addition, soybean floral buds possess morphological features that make it difficult to isolate viable male cells under aseptic conditions: i) trichomes covering the bud outer surfaces

\footnotetext{
${ }^{*}$ Author for correspondence
} 
obstacle disinfestation and obstruct filtration; ii) immature soybean anthers do not respond to in vitro stimuli to spontaneous dehiscence; iii) the number of microspores per floral bud is very low; iv) floral buds that contain higher proportion of microspores and early pollen grains are very small (3-3.5 $\mathrm{mm}$ in length), which cause difficulty in manual anther dissection; and v) 3-3.5 mm floral buds from different genotypes present different stages of microsporogenesis and microgametogenesis.

In order to establish appropriate conditions for the isolation and culturing microspores and pollen grains, a sequence of tests was carried out. Considering the limitations above mentioned, it was necessary to adapt an isolation procedure, using different genotypes and, subsequently to establish microspore cultures. The effects of medium constitution and genotypes were tested.

\section{MATERIAL AND METHODS}

\section{Plant material}

Plants of soybean cultivars Bragg, MG/BR-46 Conquista, IAS 5 and BRSMT Uirapuru were grown in a growth chamber with a $14 \mathrm{~h}$ photoperiod, light intensity of 13,500 lux and temperature of $26 \pm 3^{\circ} \mathrm{C}$. Floral buds used in the test of PTA-15 modified medium were obtained from plants grown in an experimental field localized at latitude $30^{\circ} 03^{\prime} \mathrm{S}$ and longitude $51^{\circ} 10^{\prime} \mathrm{W}$, without water-stress and in soil conditions recommended to soybean crop in South of Brazil. For disinfestations, 3-3.5 $\mathrm{mm}$ floral buds were sequentially immersed in $70 \%$ ethanol for $1 \mathrm{~min}$, $1 \% \mathrm{NaOCl}$ with a drop of detergent for $12 \mathrm{~min}$ and washed three times in sterile $\mathrm{H}_{2} \mathrm{O}$. A total of 4,045 $\mathrm{mL}$ of suspensions was produced.

\section{Microspore isolation test}

Androeciums were dissected from 3-3.5 mm immature floral buds, gently macerated with a glass rod and suspended in $4.5 \mathrm{~mL}$ liquid medium $+0.5 \mathrm{~mL}$ propionic-carmine $(0.6 \%)$ in a $50 \mathrm{~mL}$ Erlenmeyer flask. The crude extract containing $\sim 80$ anthers $\mathrm{mL}^{-1}$ was stirred for $4 \mathrm{~min}$. The culture medium was B5 (Gamborg et al., 1968) with $60 \mathrm{~g} \mathrm{~L}^{-1}$ sucrose at $\mathrm{pH}$ 6.4. Aliquots of $1 \mathrm{~mL}$ of crude extract were filtered through a $37 \mu \mathrm{m}$ nylon mesh screen and washed with the same medium by: centrifugation at $2000 \mathrm{rpm}$ for $3 \mathrm{~min}$ (previously tested); discarding $700 \mu \mathrm{L}$ medium; and resuspension in the same volume of liquid medium. The number of washes $(0,1,2,3$ and 4$)$ was tested. Each combination (cultivar $\mathrm{x}$ number of washes) was repeated twice. The quality of the suspensions was evaluated in $60 \mu \mathrm{L}$ samples of each aliquot. Microspores were counted, staged and classified on glass slides under a Zeiss Axioplan Universal microscope. An average of 300 observations per slide was performed. Constituent elements of the suspension were classified as: tetrads; whole microspores and pollen grains; non-viable or plasmolyzed microspores; burst microspores; whole sporophytic anther cells; and burst sporophytic anther cells (=debris). The normality test and analysis of variance (ANOVA) were performed on the data.

\section{Culture density test}

Floral buds from 4 cultivars were submitted to the isolating technique developed in the previous test. Suspensions were obtained using androeciums from 4,8 and 12 floral buds per $\mathrm{mL}$ of medium, with 5 repetitions. The density of the whole microspore and pollen grains was scored using a hemacytometer. The normality test, ANOVA and analysis of regression were performed on the data.

\section{Microspore viability test}

Microspores from 3-3.5 mm floral buds of cultivar BRSMT Uirapuru were isolated in sterile conditions, according to the previous isolation and density tests, in order to obtain a suspension with 5 x $10^{4}$ cells $\mathrm{mL}^{-1}$. The following factors were tested: two culture media [B5 and MS (Murashige and Skoog, 1962) including salts and vitamins]; sucrose concentration (60 and $120 \mathrm{~g} \mathrm{~L}^{-1}$ ) and $\mathrm{pH}$ (6.0 and 6.4) in a triple factorial design. The suspension was divided into $1 \mathrm{~mL}$ aliquots, placed in Corning ${ }^{\mathrm{TM}}$ plates (6 wells) and incubated at $26 \pm 1^{\circ} \mathrm{C}$ in darkness. Each combination was repeated 5 times. Microspore viability was determined by fluorochromatic reaction to fluorescein diacetate (FDA) (Heslop-Harrison and Heslop-Harrison, 1970) in samples at 0 and 28 days of incubation. Microspore responses during culture were analyzed in fresh material sampled at $0,14,28$ and 42 days, mixed with a drop of propionic-carmine on a glass slide, covered under a cover slip, and analyzed under the microscope. The normality test, ANOVA and correlation 
analysis were performed.

\section{Culture in PTA-15 modified medium}

Microspores of cultivars MG/BR-46 Conquista, IAS 5 and BRSMT Uirapuru were isolated in PTA-15 (Skinner and Liang, 1996) modified medium following the procedure above described. Aliquots of $500 \mu \mathrm{L}$ (density $5 \times 10^{4}$ cells $\mathrm{mL}^{-1}$ ) were placed in Corning ${ }^{\mathrm{TM}}$ plates (24 wells) under two conditions: liquid medium and double phase medium (liquid spread on $8 \mathrm{~g} \mathrm{~L}^{-1}$ agarose gelled medium). Four repetitions were used for IAS-5 and eight for MG/BR-46 Conquista and BRSMT Uirapuru. Cultures were incubated at $26 \pm 1^{\circ} \mathrm{C}$ in darkness. Microspore viability was determined by fluorochromatic reaction to FDA in samples at 0 and 28 days of incubation. Microspore responses during culture were analyzed under the microscope at $0,14,28$ and 42 days of incubation in samples fixed in Farmer's solution (100\% ethanol: glacial acetic acid, 3:1) and stained with propionic-carmine. Fifty four samples were collected from BRSMT Uirapuru suspension before culturing and analyzed simultaneously by fluorochromatic reaction to mithramicin according to Coleman and Goff (1985) and propionic carmine staining. The normality test, ANOVA and correlation analysis were performed.

\section{RESULTS AND DISCUSSION}

\section{Microspore isolation test}

Due to the morphological features of floral buds, isolation of soybean microspores demand individualized and selective removal of the androecium, to avoid that bracts are included in the crude extract. After removal of the androecium, maceration with a glass rod followed by magnetic stirring were essential for fragmentation of staminal tissues and microspore release from the sporangia. Due to the lack of intercellular adhesion, few microspores bursted during this step. Magnetic stirring was also suitable to isolate Oryza sativa (Cho and Zapata, 1990) and Malus domestica (Höfer et al., 1999) microspores. According to our previous observations, the microspores of the soybean cultivars tested in the present study presented an average diameter of $25 \mu \mathrm{m}$. Thus, a $37 \mu \mathrm{m}$ pore was appropriate for filtering it, although this pore size allows the passage of tetrads.
As a rule, when the bud length was 3 to $3.5 \mathrm{~mm}$, meiosis ended and only a small number of tetrads and mostly microspores and pollen grains remained. However, floral buds having the same size presented differences in the microsporogenesis and microgametogenesis stages when comparing different soybean cultivars (Lauxen et al., 2003). Floral buds of IAS 5 presented anthers in more advanced microsporogenesis stages while the other cultivars had anthers containing more than $94 \%$ of microspores (Figure 1a). When microspores were isolated, the percentage of degraded microspores (whole but non-stained or plasmolyzed) was significantly higher for IAS $5(\mathrm{Pr}>\mathrm{F}=0.0001)$. ANOVA did not detect a significant effect of the number of washes on the percentage of degraded microspores $(\mathrm{Pr}>\mathrm{F}=0.8825)$.

The constituent elements of the suspension were a small proportion of burst microspores and sporophytic cells and a majority of whole microspores and pollen grains (Figure 1b). The category of whole microspores included either stained or non-stained microspores. The percentage of burst microspores was not significantly different among cultivars $(\operatorname{Pr}>\mathrm{F}=0.1019)$ and decreased significantly with the number of washes $(\operatorname{Pr}>\mathrm{F}=0.0086)$. This observation indicated that bursting preceded washes, resulting from the maceration procedure.

Concerning the proportion of debris, a difference was detected among genotypes. Cultivars Bragg and IAS 5 presented a significantly higher proportion of debris when compared to MG/BR-46 Conquista and BRSMT Uirapuru ( $\mathrm{Pr}>\mathrm{F}=0.0001)$. After the first wash, the proportion of debris decreased significantly $(\mathrm{Pr}>\mathrm{F}=0.0001)$.

The occurrence of whole sporophytic cells in culture was rare, i.e. 5 out of the 12,272 observations and it could be accounted for mesh pore widening. In the subsequent experiments, the careful examination of the mesh under a stereomicroscope avoided the presence of whole sporophytic cells in culture. After three washes, the suspension presented suitable quality to establish cultures. The same number of washes was used to isolate microspores in Zea mays (Huang and Keller, 1989; Pretová et al., 1993), Brassica species (Huang and Keller, 1989; Barro and Martín, 1999; Dias, 1999) and Malus domestica (Höfer et al., 1999). The technique described here allowed the establishment of suspensions containing microspores and pollen 
grains. In order to separate homogeneous populations, exclusively with microspores or pollen grains, it would be necessary to complement the technique, for instance, by means of Percoll density gradient centrifugation (Kyo and Harada, 1986).
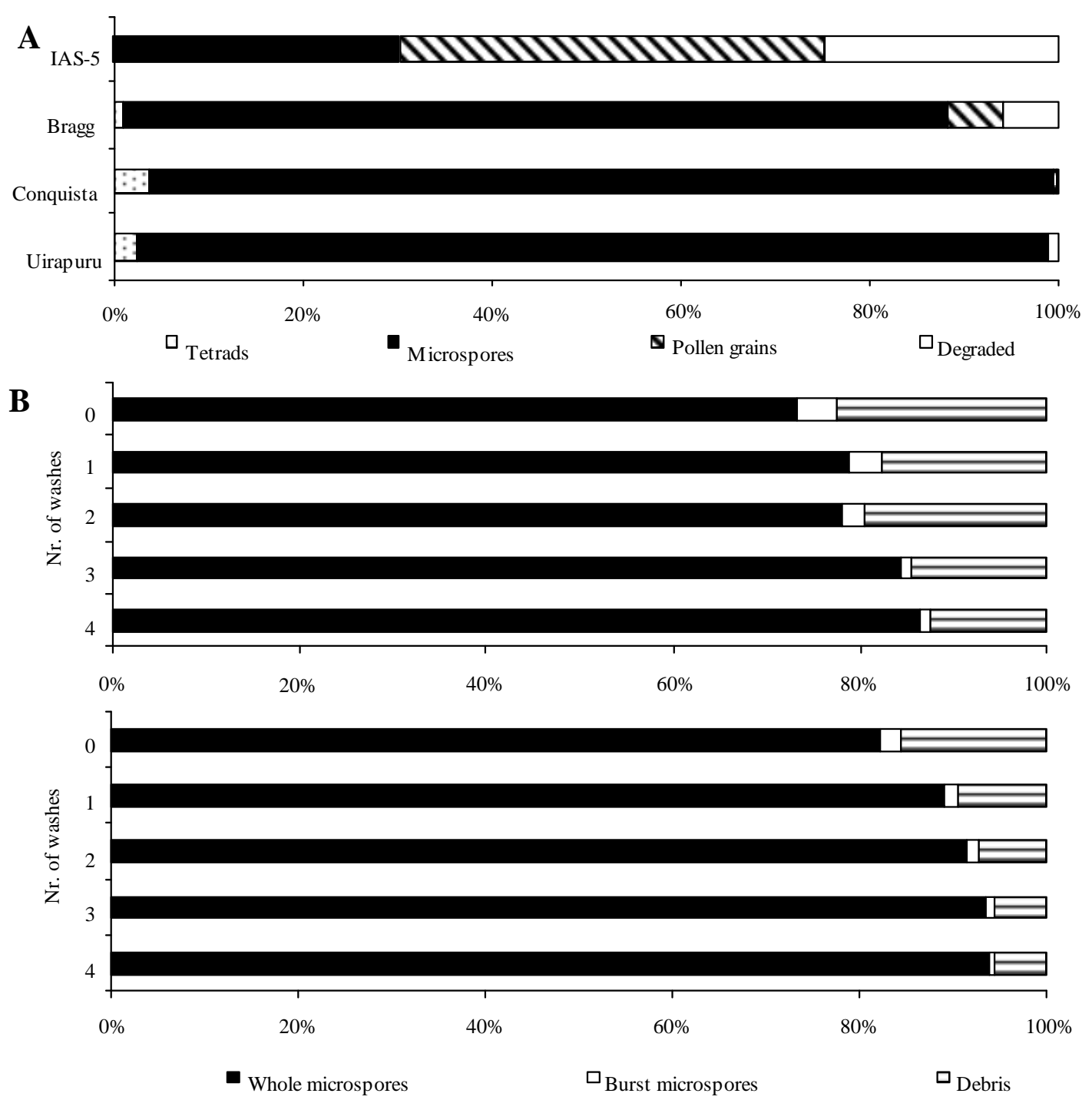

Figure 1 - Microspore isolation test. A. Percentage of microspores in the suspension obtained from 3-3.5 mm floral buds according to developmental stage of four soybean cultivars (IAS 5, Bragg, MG/BR-46 Conquista and BRSMT Uirapuru). B. Percentage of constituent elements of suspension according to number of washes. Cultivars IAS 5 and Bragg (above) and cultivars MG/BR-46 Conquista e BRSMT Uirapuru (below) were separated as a consequence of statistical differences.

\section{Culture density test}

Culture density has an important role in the proportion of responsive microspores. Usually, microspore density in culture varies from $10^{4}$ to $10^{5}$ cells $\mathrm{mL}^{-1}$. Very low embryo yields were found at microspores densities lower than $2 \times 10^{4}$ in B. oleracea (Duijs et al., 1992). Both number of floral buds $\mathrm{mL}^{-1}(\operatorname{Pr}>\mathrm{F}=<0.0001)$ and genotype
$(\operatorname{Pr}>\mathrm{F}=0.0004)$ showed highly significant effects on density, without interaction between sources of variation $(\mathrm{Pr}>\mathrm{F}=0.3821)$. The cultivar Bragg displayed the highest number of microspores (Fig. 2). The overall average were $5.7 \times 10^{5}$ cells $\mathrm{mL}^{-1}$ in Bragg, $4.1 \times 10^{5}$ in BRSMT Uirapuru, $3.8 \times 10^{5}$ in MG/BR-46 Conquista and $3.1 \times 10^{5}$ in IAS 5 . These differences determined a significant linear 
regression equation for each cultivar. The correlation coefficient ( $\mathrm{r}$ ) between number of buds and density was significant for three out of four cultivars, except for IAS 5. This result could be accounted for the advanced stage of microgametogenesis (Figure 1a). Microspore release from sporangia and passage through mesh screen became progressively less efficient along bud development due to tissue rigidity and volume.

Despite the significant $r$, the final density varied as a consequence of differences among anthers, buds and cultivars. This observation indicated that culture density should be adjusted for each isolation procedure. Obtaining an appropriate culture density is a very laborious task in soybean. To obtain $10 \mathrm{~mL}$ of suspension with $5 \times 10^{4}$ cells $\mathrm{mL}^{-1}$, it was necessary to dissect androeciums of 100 to 170 floral buds. For comparison, 15 to 20 Petunia buds (Sangwan and Norrel, 1975) and 10 B. napus buds (Huang and Keller, 1989) were enough to produce $10 \mathrm{~mL}$ of liquid culture with a density of $1 \times 10^{4}$ and 2 to $3 \times 10^{4}$, respectively.

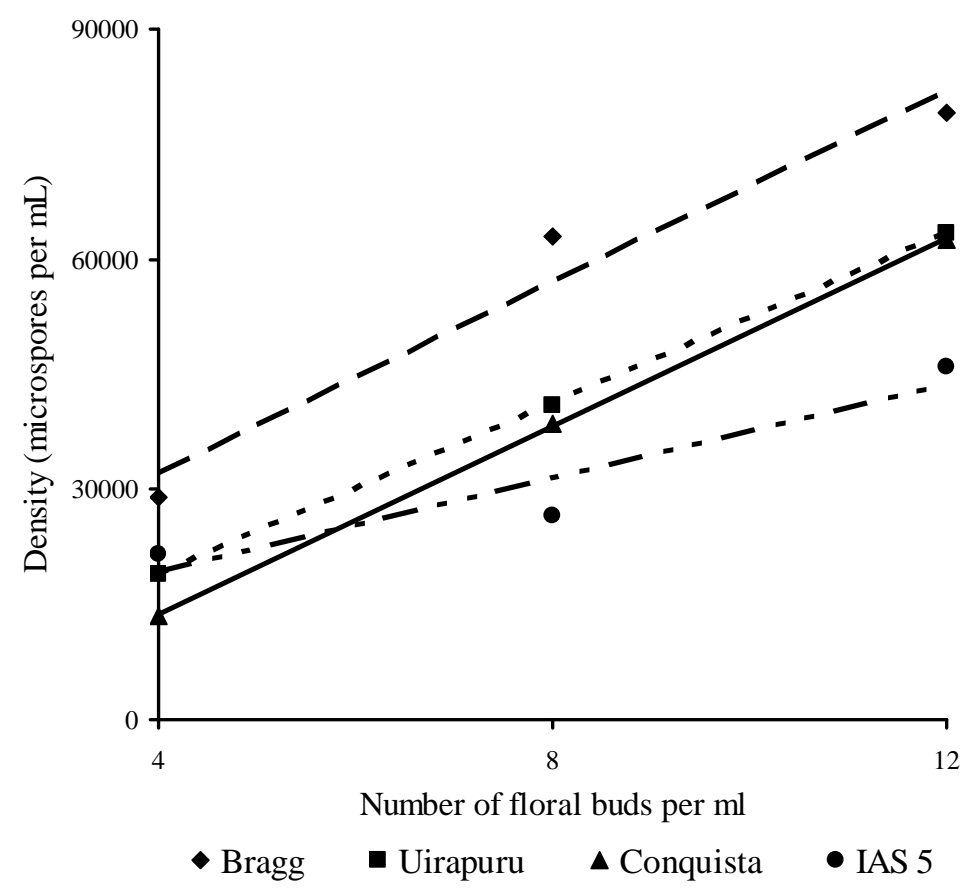

Figure 2 - Culture density test. Trend lines relating the number of floral buds of four soybean cultivars and the density (microspores and pollen grains per $\mathrm{mL}$ of culture) in the final suspension. Linear regression equation: Bragg: $y=6250 x+7000$ $\left(\mathrm{r}=0,5921^{*}\right)$; BRSMT Uirapuru: $\mathrm{y}=5562 \mathrm{x}+3333,3(\mathrm{r}=0,8558 *) ; \mathrm{MG} / \mathrm{BR}-46$ Conquista: $\mathrm{y}=6125 \mathrm{x}-10833,3(\mathrm{r}=0,7852 *)$; and IAS 5: $\mathrm{y}=3062,5 \mathrm{x}+6833,3$ ( $\mathrm{r}=0,4422$, non-significant).

\section{Microspore viability test}

Table 1 shows the results of assessment of microspore stainability by propionic-carmine and fluorochromatic reaction to FDA. The percentage of fluorochromatic reaction (35\% in average) was lower than that observed previously in fresh anthers (approximately 50\%; data not shown). The percentage of carmine-stained microspores was higher than the percentage of microspores that reacted to FDA. The correlation coefficient between (r) carmine and FDA results was not significant either at the beginning of the culture ( $\mathrm{r}$ $=-0.296)$ or after 28 days $(r=0.054)$. This result confirmed previous observations that the two methods provided different inferences on the evaluation of microspore response to culture (Rodrigues et al., 2005a). ANOVA detected significant effects of media $(\mathrm{Pr}>\mathrm{F}=0.0301)$ and $\mathrm{pH}$ $(\mathrm{Pr}>\mathrm{F}=0.0108)$ on decreasing microspore viability after 28 days of culture. Although the effect of 
sucrose concentration was not significant $(\operatorname{Pr}>\mathrm{F}=0.3333)$, there was significant interaction between medium and sucrose concentration $(\operatorname{Pr}>\mathrm{F}<0.0001)$. Decrease of viability was smaller when $60 \mathrm{~g} \mathrm{~L}^{-1}$ sucrose was combined with B5 medium (Table 1).

Viability of microspores cultured in B5 medium with $60 \mathrm{~g} \mathrm{~L}^{-1}$ sucrose and $\mathrm{pH} 6.4$ was higher after 28 days than at the beginning of the culture (Table 1). This result could be accounted for experimental error, such as defective sampling and variation on the optimum moment of fluorescein retention by plasmalema (Heslop-Harrison and HeslopHarrison, 1970). Carmine squashes have been used to determine the nature of the embryogenic microspores since the first description of plant androgenesis in vitro (Guha and Maheshwari, 1966). Carmine allows a distinction between vegetative and generative nuclei and is useful to follow cell division and events causing degradation. The disadvantage is that carmine indiscriminately stains both live and dead cells.

Only two multicellular structures were found out of the 12,272 observations: a four-celled structure in MS medium (not shown) and an eight-celled one in B5 medium (Fig. 3c). The latter had a translucent covering similar to callose. Although such structures were formed in vitro, there was no evidence of their haploid origin. Anyway callose deposition has been thought to be a prerequisite for embryogenesis (Verdeil et al., 2001). The higher survival of microspores in B5 indicated that this medium provided chemical and physical conditions for cell maintenance, but not necessarily to trigger embryogenesis.

Table 1 - Fluorochromatic reaction to FDA and stainability to propionic-carmine in microspores and pollen grains of cultivar BRSMT Uirapuru at 0 and 28 days of culture in different culture media. The columns $\neq$ show the difference between day 0 and 28.

\begin{tabular}{|c|c|c|c|c|c|c|c|c|}
\hline \multicolumn{3}{|c|}{ Treatments } & \multicolumn{3}{|c|}{$\begin{array}{l}\text { Fluorochromatic } \\
\text { reaction to FDA }\end{array}$} & \multicolumn{3}{|c|}{$\begin{array}{c}\text { Propionic-carmine } \\
\text { staining }\end{array}$} \\
\hline Medium & Sucrose & $\mathbf{p H}$ & Day 0 & Day 28 & $\neq$ & Day 0 & Day 28 & $\neq$ \\
\hline B5 & 60 & 6.0 & 29 & 22 & 7 & 99 & 99 & $<1$ \\
\hline B5 & 60 & 6.4 & 31 & 39 & -8 & 99 & 97 & 2 \\
\hline B5 & 120 & 6.0 & 37 & 19 & 18 & 99 & 96 & 3 \\
\hline B5 & 120 & 6.4 & 33 & 16 & 17 & 99 & 99 & $<1$ \\
\hline MS & 60 & 6.0 & 45 & 23 & 22 & 96 & 91 & 5 \\
\hline MS & 60 & 6.4 & 40 & 20 & 20 & 97 & 85 & 12 \\
\hline MS & 120 & 6.0 & 36 & 22 & 14 & 94 & 85 & 9 \\
\hline MS & 120 & 6.4 & 28 & 25 & 3 & 97 & 82 & 15 \\
\hline \multicolumn{3}{|c|}{ General average } & 35 & 23 & 12 & 98 & 92 & 6 \\
\hline
\end{tabular}

\section{Culture in PTA-15 modified medium}

In Medicago sativa microspore culture, the PTA15 medium was used to trigger microspore embryogenesis. In the isolation procedure, the pelleted microspores were resuspended in PTA-15 liquid and spread on PTA-15 gelled with agar or Gelrite (Skinner and Liang, 1996). Therefore, PTA-15 modified medium was tested in both liquid and double phase in soybean microspore culture. A total of 24,218 carmine-staining observations was scored from samples at 0,7 and 14 days of culture. Degraded (non-stained and plasmolysed) microspores represented around $1.5 \%$ of the total. This value was lower than those obtained in B5 and MS media. Multicellular structures similar to those already recorded in B5 and MS media were also observed.

Typical embryogenic events were observed in the PTA-15 modified medium, including enlargement of the microspore size (Sangwan and Norrel, 1975; Höfer et al., 1999) and multicellular pollen grain formation (Fig. 3b). Multicellular pollen grains presented 3 to 5 cells, sometimes varying in size but with similar nuclei, without vegetative and generative features. The multicellular pollen grains occurred indiscriminately in double phase and liquid medium, but at very low frequencies: only 7 out of 3,688 $(0.2 \%)$ microspores in IAS 5 and 29 out of $7,173(0.4 \%)$ in BRSMT Uirapuru. In the latter cultivar, the structures presented a higher 
number of cells. Microspore viability evaluated by FDA decreased to 21,28 and $1 \%$ in MG/BR-46 Conquista, IAS 5 and BRSMT Uirapuru, respectively, after 28 days of culture, independently of the occurrence of embryogenic events.

Comparing fluorochromatic reaction to mithramycin and stainability to propionic-carmine, a total of 26,236 microspores and pollen grains were analyzed. The fluorochrome allowed significant better characterization of the morphology of typical and atypical nuclei. ANOVA detected significant differences between observations obtained by the two techniques applied to the same samples $(\operatorname{Pr}>\mathrm{F}<0.001)$. Symmetrical nuclei in pollen grains before culture were recorded only by means of fluorochromatic reaction to mithramycin (Fig. 3a).

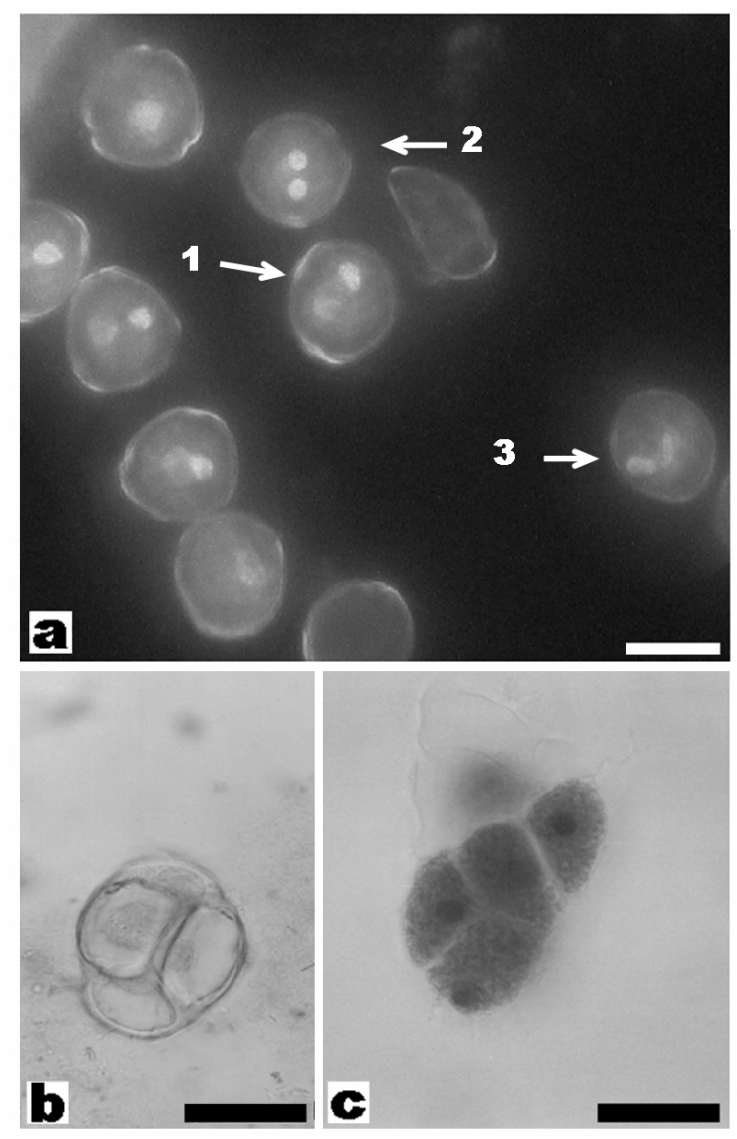

Figure 3 - Isolated microspores and pollen grains of the soybean cultivar BRSMT Uirapuru. a. Fluorochromatic reaction to mithramycin, showing typical (1), symmetrical generative-like (2) and symmetrical vegetative-like (3) nuclei in pollen grains before culture. b. Multicellular pollen grain after 7 days of culture in PTA-15 modified medium. c. Eight-celled multicellular structure after 14 days of culture in B5 medium (Bars $=20 \mu \mathrm{m})$.

\section{Final considerations}

Procedures developed in these laborious assays allowed to isolate, culture and analyze in vitro responses of soybean microspores and pollen grains in the absence of sporophytic tissues. The isolation procedure allowed obtaining mixed suspensions. To separate homogeneous populations, exclusively with microspores or pollen grains, it would be necessary to complement the technique. The results obtained with PTA-15 medium can be seen as a good starting result to achieve the recovery of androgenic plants in soybean. The next challenge would be to determine culture conditions to embryo formation and plant regeneration. 


\section{ACKNOWLEDGMENTS}

The authors are grateful to Dr. Vera L.S.V. Gayeski and Dr. Rosane N. Garcia (Dep. de Genética - UFRGS) for help in fluorescence microscopy and to Dr. Leones Alves de Almeida (Centro Nacional de Pesquisa da Soja - Embrapa) for supplying the seeds. This research was supported by Conselho Nacional de Desenvolvimento Científico e Tecnológico (CNPq), Coordenação de Aperfeiçoamento de Pessoal de Nível Superior (Capes) and Fundação de Amparo à Pesquisa do Estado do Rio Grande do Sul (Fapergs).

\section{RESUMO}

Nas últimas três décadas, a pesquisa em embriogênese do micrósporo de soja restringiu-se ao cultivo in vitro de anteras, com inúmeras limitações, como o pequeno número de micrósporos responsivos e o alto potencial embriogênico dos tecidos esporofíticos. Por isso, foi executada uma seqüência de testes visando ao estabelecimento de condições adequadas para o isolamento e o cultivo in vitro de micrósporos e grãos de pólen, como um sistema alternativo ao cultivo de anteras. Inicialmente, uma técnica de isolamento foi desenvolvida usando botões florais de quatro cultivares de soja (Bragg, IAS 5, MG/BR-46 Conquista e BRSMT Uirapuru), a qual possibilitou o estabelecimento de cultivos com características e densidade satisfatórias. Posteriormente, diferentes condições de cultivo foram testadas. Apesar de os meios B5 e MS serem recomendados para o cultivo de anteras de soja, o melhor resultado foi obtido em meio PTA15 modificado, como o aumento do tamanho dos micrósporos e a formação de $0,4 \%$ de grãos de pólen multicelulares na cultivar BRSMT Uirapuru.

\section{REFERENCES}

Barro, F. and Martín, A. (1999), Response of different genotypes of Brassica carinata to microspore culture. Plant Breeding, 118, 79-81.

Cho, M. S. and Zapata, F. J. (1990), Plant regeneration from isolated microspore of indica rice. Plant Cell Physiol., 31, 881-885.
Coleman, A. W. and Goff, L. J. (1985), Applications of fluorochromes to pollen biology. I. Mithramycin and 4'-6-diamidino-2-phenylindole (DAPI) as vital stains and for quantitation of nuclear DNA. Stain Technol., 60, 145-154.

Dias, J. C. S. (1999), Effect of activated charcoal on Brassica oleracea microspore culture embryogenesis. Euphytica, 108, 65-69.

Duijs, J. G.; Voorrips, R. E.; Visser, D. L. and Custers, J. B. M. (1992), Microspore culture is successful in most crop types of Brassica oleracea L. Euphytica, 60, 45-55.

Gamborg, O. L.; Miller, R. A. and Ojima, K. (1968), Nutrient requirements of suspensions cultures of soybean root cells. Exp. Cell. Res., 50, 151-158.

Guha, S. and Maheshwari, S. C. (1966), Cell division and differentiation of embryos in the pollen grains of Datura in vitro. Nature, 5057, 97-98.

Heslop-Harrison, J. and Heslop-Harrison, Y. (1970), Evaluation of pollen viability by enzymatically induced fluorescence: Intracellular hydrolysis of fluorescein diacetate. Stain Technol., 45, 115-120.

Höfer, M.; Touraev, A. and Heberle-Bors, E. (1999), Induction of embryogenesis from isolated apple microspore. Plant Cell Rep., 18, 1012-1017.

Hu, C.; Yin, G. and Bodanese-Zanettini, M. H. (1996), Haploid of Soybean. In: Mohan, S. J.; Sopory, S. K. and Veilleux, R. E. (Eds.). In vitro Haploid Production in Higher Plants. v. 3: Important Selected Plants. Dordrecht: Kluwer Academic. pp. 377-395.

Huang, B. and Keller, W. A. (1989), Microspore culture technology. J. Tiss. Cult. Methods, 12 : (4), 171-178.

Ivers, D. R.; Palmer, R. R. and Fehr, W. R. (1974), Anther culture in soybean. Crop Sci., 14, 891-893.

Kaltchuk-Santos, E.; Mariath, J. E.; Mundstock, E.; Hu, C. and Bodanese-Zanettini, M. H. (1997), Cytological analysis of early microspore divisions and embryo formation in cultured soybean anthers. Plant Cell Tiss. Org. Cult., 49, 107-115.

Kyo, M. and Harada, H. (1986), Studies on conditions for cell division and embryogenesis in isolated pollen culture of Nicotiana rustica. Plant Physiol., 79, 90-94.

Lauxen, M. S.; Kaltchuk-Santos, E.; Hu, C. Y.; Callegari-Jacques, S. M. and Bodanese-Zanettini, M. H. (2003), Association between floral bud size and development stage in soybean microspore: implications for anther culture. Braz. Arch. Biol. Technol., 46, 515-520.

Liu, D. P. and Zhao, G. L. (1986), Callus formation from pollen culture in vitro of soybean. Soybean Sci., 5, 17-20.

Murashige, T. and Skoog, F. (1962), A revised medium for rapid growth and bioassays with tobacco tissue cultures. Physiol. Plantarum, 15, 473-497. 
Pretová, A.; Ruijter, N. C. A.; Van Lammeren, A. A. M. and Schel, J. H. N. (1993), Structural observations during androgenic microspore culture of the $4 \mathrm{c} 1$ genotipe of Zea mays L. Euphytica, 65, 61-69.

Rodrigues, L. R.; Oliveira, J. M. S.; Mariath, J. E. A. Iranço, L. B. and Bodanese-Zanettini, M. H. (2005a), Anther culture and cold treatment of floral buds increased symmetrical and extra nuclei frequencies in soybean pollen grains. Plant Cell Tiss. Org. Cult., 81 : (1), 101-104.

Rodrigues, L. R.; Oliveira, J. M. S.; Mariath, J. E. A. and Bodanese-Zanettini, M. H. (2005b), Histology of embryogenic responses in soybean anther culture. Plant Cell Tiss. Org. Cult., 80 : (2), 129-137.

Rodrigues, L. R.; Oliveira, J. M. S.; Mariath, J. E. A. and Bodanese-Zanettini, M. H. (2004a), Effects of light conditions and 2,4-D concentration in soybean anther culture. Plant Growth Regul., 44 : (2), 125133.

Rodrigues, L. R.; Terra, T. F.; Bered, F. and BodaneseZanettini, M. H. (2004b), Origin of embryo-like structures in soybean anther culture investigated using SSR marker. Plant Cell Tiss. Org. Cult., 77 : (3), 287-289.

Sangwan, R. S. and Noreel, B. (1975), Induction of plants from pollen grains of Petunia cultured in vitro. Nature, 257, 222-224.

Skinner, D. Z. and Liang, G. H. (1996), Haploidy in alfalfa. In: Mohan, S. J.; Sopory, S. K. and Veilleux, R. E. In vitro Haploid Production in Higher Plants. v. 3: Important Selected Plants. Dordrecht: Kluwer Academic. pp. 365-375.
Tang, W. T.; Ling, T. S. and Chang, C. S. (1973), Effects of kinetin and auxin on callus formation in anther tissue cultures of soya bean. J. Agri. Asso. China, 83, 1-7.

Verdeil, J. L.; Hocher, V.; Huet, C.; Grosdemange, F.; Escoute, J.; Ferriere, N. and Nicole, M. (2001), Ultrastructural changes in coconut calli associated with the acquisition of embryogenic competence. Ann. Bot., 88, 9-18.

Yin, G. C.; Zhu, Z. Y.; Xu, L.; Chen, L.; Li, X. Z. and Bi, F. Y. (1982), Studies on induction of pollen plant and their androgenesis in Glycine max (L.) Soybean Sci., 1, 69-76.
Received: November 30, 2004; Revised: October 03, 2005; Accepted: March 30, 2006. 